\title{
Evaluation of Climate Change Impacts and Adaptation Options Using Risk-Based Hydro- Economic Model in Ajichay Basin, Iran
}

fatemeh sani ( $\sim$ fateme.sani69@yahoo.com )

University of Tabriz Faculty of Agriculture

Ghader Dashti

University of Tabriz Faculty of Agriculture

Abolfazl Majnooni

University of Tabriz Faculty of Agriculture

Javad Hosseinzad

University of Tabriz Faculty of Agriculture

Research Article

Keywords: Adaptation, Ajichay Basin, Climate Change, Hydro-Economic Model, Quadratic Risk Programming, WEAP-MABIA

Posted Date: June 1st, 2021

DOI: https://doi.org/10.21203/rs.3.rs-554394/v1

License: (c) (i) This work is licensed under a Creative Commons Attribution 4.0 International License. Read Full License 


\title{
Evaluation of Climate Change Impacts and Adaptation Options Using Risk-Based Hydro-Economic Model in Ajichay Basin, Iran
}

\author{
Fatemeh Sani", Ghader Dashti, Abolfazl Majnooni, Javad Hosseinzad \\ Department of agricultural economics, University of Tabriz, Tabriz, Iran \\ *Corresponding author E-mail: fateme.sani69@yahoo.com
}

\begin{abstract}
\end{abstract}
Climate change is one of the main issues in the $21^{\text {st }}$ century and has been felt in many regions of world such as the Ajichay basin. The greatest impact of climate change is on the water resource sector. Projected changes in precipitation, temperature and river runoff will largely affect the water cycle and hydrological systems with important results for economic sector. Therefore, the current study aims to investigate the impact of climate and water management scenarios on water resources, cropping patterns, yields, and profits of farmers using a hydro-economic model. Quadratic risk programming was used for economic modeling, and WEAP-MABIA was applied for hydrological modeling. The necessary data were collected from questionnaires completed by 210 farmers selected by stratified random sampling during 2018. The HadCM3 model and LARS-WG downscaling were used to generate daily climatic data under the emissions of A2, B1, and A1B scenarios. The results showed that climate change could reduce the profit and employment rate in the agricultural sector and cause a shift in cropping patterns to crops with low water requirements. In addition to the efficient use of allocated water, the application of increasing irrigation efficiency scenario could raise farmers' profits, providing them with a better situation than the agricultural water reduction scenario. Overall, the findings of the current study revealed that without changing the management strategies there will be a considerable reduction in water resource and crop yield in near future.

Keywords: Adaptation, Ajichay Basin, Climate Change, Hydro-Economic Model, Quadratic Risk Programming, WEAP-MABIA

\section{Introduction}

As an essential environmental issue in the $21^{\text {st }}$ century, climate change has been the center of attention for many scientists and researchers. Climate change affects agriculture, economy, forestry, industry, tourism, water, energy, and even financial markets and insurance systems (Kemfert, 2009). However, agriculture depends on climate more than in other sectors. In other words, climate is the main determining force of the place, resource, production, and the efficiency of agricultural activities. Production is expected to be limited to more than half of arable land in the next 50 years with continued global warming (Cattivelli et al., 2008). It can be concluded that any type of climate change in the future will affect agricultural products seriously on different levels and result in decreases in the total factor productivity, farmer's incomes, cropping area, and the number of people involved in the agriculture sector (Gul et al., 2019).

As agriculture is considered an economic activity for supplying food and guaranteeing perpetual food safety, climate changes can harm the safety (FAO, 2012). Lakes as natural water sources are affected by climatic, hydrologic, 
and geomorphologic changes, as well as human activities around their basins. Any change in alignment or area of the lakes can affect the economy, agriculture, and other human activities around the lake (Cheng and Li., 2020).

Ajichay, as one of the main agricultural areas and a source of water consumption around the Lake Urmia, has lost its efficiency as the supplier of water and is considered as the center of crisis due to changes in the climate, lack of precipitation, and human factors, such as overuse of groundwater, inappropriate cultivation patterns, and the expansion of economic sectors. Data were collected from Sarin Dizaj hydrometric station (the basin output station) and the longterm (1986-2016) average of the annual output flow is 230 MCM from Ajichay basin. It is important to note that the average annual output flow during 1986-1997 (before the decrease in the lake level) was 360 MCM, which decreased to 100 MCM between 1998 and 2016. As recently approved by the Ministry of Energy in 2017, however, the ecological water right of the lake supplied from Ajichay is set as $220 \mathrm{MCM}$ annually, which is $120 \mathrm{MCM}$ more than the average annual outflow that should be provided from the basin (ULRP, 2018).

In 2015, Tabriz, Sarab, Bostan Abad, Heris, Azarshahr, Osku, and Shebestar included 23, 38, 12, 8, 7, 7, 3, and $2 \%$ of the whole irrigated cropping area around Ajichay, respectively. The share of Tabriz and Sarab in aquaculture was $61 \%$ and, Sarab was considered as the main center of agriculture around the Ajichay basin. The biggest fruit trees also belonged to Tabriz, Azarshahr, Sarab, and Osku, including 28, 17, 16, and 15\% of the whole garden areas around the basin. Having the main branches of Ajichay, Sarab has a more influential role in producing horticultural and agronomy products and, thus, more water consumption. Therefore, managing water consumption in Sarab County is suggested to resolve the decreased quality and quantity of water in the Ajichay basin.

The basin is also facing more water requirement due to the expansion of the region and changes in the climate; there will be extra pressure on the Ajichay basin for supplying the necessary water. Management scenarios, such as low irrigation of agricultural products, reducing the share of agricultural water, increasing the efficiency of irrigation, and shifting cropping patterns to products with lower water consumption, can play an influential role in decreasing water consumption and balancing water sources in the Ajichay basin.

Managing water resources requires a thorough consideration of all the elements and the interactions among human activities, economy, earth, and water resources; in other words, it requires taking into account the economic, social, and environmental factors (GWP, 2000). Thus, methods, such as the hydro-economic model, are appropriate for policymakers to evaluate water resources (Blanco- Gutiérrez, 2013). It is also a suitable method for assessing the effects of climate change on water and agriculture.

Currently, there are various research projects on the effects of climate change on agriculture and managing water resources. As an instance, Tramblay et al. (2020) examined climate change impacts on water resources in the Mediterranean, Zhang et al. (2017) studied the impact of climate change on the agriculture sector in China from 1980 to 2010, Veijalainen et al. (2010) investigated the impact of climate change on hydrology and water resources of Vuoksi River in Finland, Tubiello et al. (2002) developed a model to investigate the effects of climate change on US crop and many other studied that focused on the climate impact issues (Easterling et al., 2003; laux et al. 2010; wang et al. 2012; Ahmad and Afzal, 2020).

The studies mentioned above have a focus on either the supply or demand management as an aspect of agricultural water management. However, it is necessary to consider both aspects of supply and demand through hydro-economic 
models, which have been the center of attention for many researchers studying the management of both the supply and demand of agricultural water (Eamen et al. 2020).

Medellan-Azuara et al. (2010) studied a vast domain of options for managing the water systems in North California and Mexico through a hydro-economic model. They claimed that the optimized hydro-economic model could evaluate different options for water management and the allocation of water for various demands (agricultural, environmental, and drinking water). Elsewhere, Kahil et al. (2015) applied the hydro-economic model to study the management policies of efficient water and necessary adaptations with changes in the climate in the Jucar River basin. Their findings revealed that drought negatively affected the environmental and agricultural activities and reduced social welfare to a range of 63-138 million Euros. In addition, the study of water management policies revealed that the establishment of water market was an appropriate management tool for confronting the economic effects of drought.

Using the hydro-economic model, Varela-Ortega et al. (2016) investigated the effects of climate change around the Guadiana River basin. Based on their findings, a severe climate change would result in a $10-50 \%$ reduction in available water, up to $20 \%$ decrease in the crop yield, and a 10-20\% decrease in the income scenario, as well as up to $20 \%$ increase in the water requirement of the crops from 2010-2040.

Rafiei Darani et al. (2017) studied the effects of modifying the policies of marketing networks on the agricultural products in Neishaboor plain using a hydro-economic model. They applied the WEAP model for the hydrologic section and a positive planning model for the economic section. The findings revealed that modification in marketing networks led to changes in the. Amin et al. (2018) studied the effects of climate change and social-economic scenarios on the present and future water demands around the basin of the Indus River in Pakistan using a hydro-economic model. A set of managing and climate scenarios were simulated for upstream Indus River from 2006 to 2050 using the WEAP model. Their results indicated that a lack of attempt to change the available situation would result in more water demand, increasing unmet demand up to $134 \mathrm{MCM}$.

Aien and Alizadeh (2021) developed a generic novel hydro-economic methodology for optimal planning of an integrated development scheme. results show that optimizing irrigation-leaching schedule leads to significant improvement of the economic value of water compared to the status quo, while construction and operation of structural projects result in a dramatic decrease in the economic value of water due to increase in both costs and leaching-related water usage.

Many of the studies based on the hydro-economic model assume a neutral risk for farmers and ignore high-risk accidents in agricultural activities. A few studies have also demonstrated risk-aversion behavior among farmers (Rosenzweig \& Binswanger, 1992; Von Neuman \& Morgenstern, 1994; Chavas, 2004), and some of others have focused on the risk in the hydro-economic model (Varela-Ortega et al., 2011; Blanco- Gutiérrez, 2013; Foster et al., 2014; Esteve et al., 2015; Exposito et al., 2020; Knowling et al., 2020). Most studies have benefitted from different hydrologic models, such as MIKE BASIN, MODSIM, SWAT, and WaSIM. A few studies have applied WEAP along with social-economic models. As an instance, Purkey et al. (2008) combined WEAP and econometric models for estimating the effects of climate change on agricultural water. Additionally, Varela-Ortega et al. (2011) applied WEAP and risk with an optimized economic model for evaluating climate uncertainty on groundwaters. 
The review of studies revealed that local studies approached climate change from only economic or hydrological aspects. Thus, the focus of the current study is to evaluate the effects of climate change on agriculture using a hydroeconomic model, which is very important from a management point of view. Ignoring hydrological issues in economic evaluation of climate change results a (more or less) deviation from limits in estimating the effects. The current research fills the gap by combining two water resources planning and mathematical planning models. Besides, similar local studies with common material and approaches (hydro-economic models) ignore the risk-aversion behavior of farmers and eliminate the risk factors from the hydro-economic model. Thus, the current study is novel because it adds the risk factor to this model.

\section{Material and method}

\subsection{Location}

The location of the current study was the Ajichay basin with an area of around $12600 \mathrm{~km}^{2}$ as the biggest sub-basin of the Urmia Lake after the Zarrinerood sub-basin. It is located in the north-west of Iran (East Azerbaijan Province) and eastern part of Urmia Lake, with geographic coordinates of $46^{\circ} 45^{\prime}$ and $46^{\circ} 45^{\prime} \mathrm{E}$ and $46^{\circ} 45^{\prime}$ and $28^{\circ} 38^{\prime} \mathrm{N}$. Tabriz, Azarshahr, Sarab, Bostan Abad, Heris, and Osku are the main urban areas around the Ajichay Basin. Based on the studies by the Regional Water Organization of East Azerbaijan, there are 10 main aquifers in this basin, among which Sarab, Asbforushan, Duzduzan, and a part of Mehraban aquifer are located in Sarab County (Fig. 1).

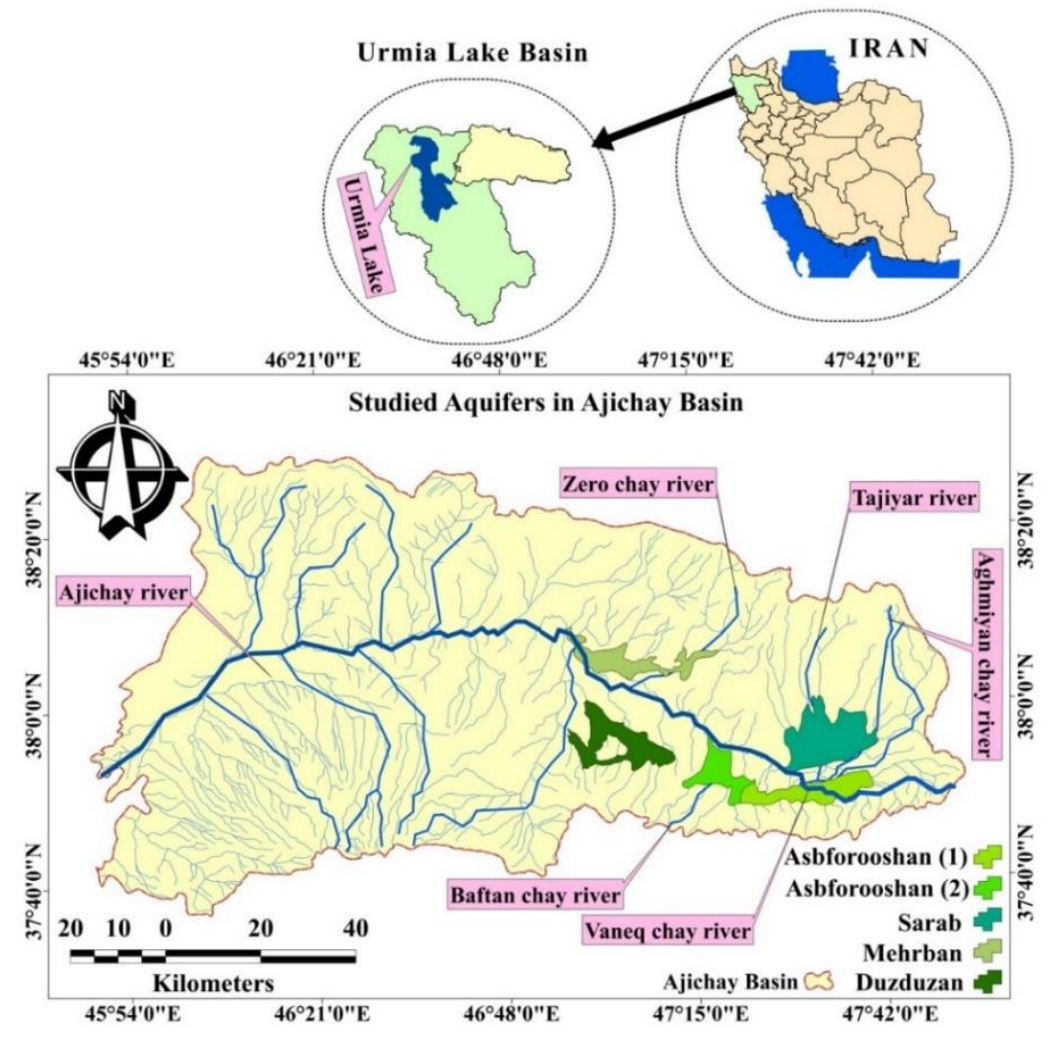

Fig. 1. An Overview of the Ajichay Sub-basin 
To include the variations in farmers' habits, water resources, and fertility of lands, the Ajichay basin was divided into 36 plains. The first step was to determine the primary borders of agricultural lands and plains through agricultural statistics and information, boundaries of aquifers, and Google Earth. Totally, 36 plains and agricultural lands were determined around the basin of Ajichay. Then, the input areas (where rivers enter the plains and agricultural areas) in each agricultural area were determined using Google Earth, which was introduced as the output for upstream subbasins (mountainous sub-basins) and that for downstream sub-basins throughout the process of extracting sub-basins in GIS environment. Therefore, mountain and plain areas were separated for all rivers and their branches to the extent of possibility.

There are two benefits to this process. Firstly, there is the possibility of separating the hydrologic modeling of mountainous areas from plains and the agricultural regions (slope areas) and estimating their variables separately, which will lead to an increase in the modeling accuracy and the estimation of variables (especially surface runoffs, evaporation, and water transpiration). Secondly, it allows the determination of input flow to each plain and agricultural area through modeling.

\subsection{The hydro-economic model}

Generally, hydro-economic models include hydrologic and economic elements. Thus, the main framework of the current study is patterned based on these two elements. Both economic (Mathematical Programming Method, MPM) and hydrologic (WEAP-MABIA) models were performed separately, while the output of one model was used as an input for the other model. The next section explains the properties of each model and selected scenarios.

\subsection{The economic model}

MPM is an optimization model that shows farmers' behaviors in risky situations through a risk-based quadratic risk programming (QRP) method. In this model, the optimal amount of land is determined for allocating to different products. The purpose of this model is to maximize the expected farmers' utility to some technical and structural restrictions. MPM is widely used to analyze managing agricultural resources and decision-making about cropping patterns (Varela-Ortega et al., 2011; Blanco- Gutiérrez et al., 2013; Esteve et al., 2015). It is considered an appropriate model for the analysis of issues related to agriculture and natural resources as it represents the relationship between economic elements (such as costs and incomes) and physical and environmental elements of farms (such as limitation in natural resources or pollution caused by production) (Buysse et al. 2007).

The objective function (Equation 1) shows the maximum expected utility of farmers, which is calculated by subtracting the risk element from the net income (Z) for each crop (Hazell \& Norton, 1986). This model not only includes the farmers' goals and limitations, but can also involve the amount of beliefs about the risk perceptions and risk attitudes. According to Hazell and Norton (1986), it is possible to calculate the risk aversion coefficient of farmers through creating a planning model and changing the risk-aversion parameter of farmers. The risk aversion coefficient the current program. 
The risk element is a combination of farmers' risk-aversion coefficient $(\varphi)$ and the standard deviation of income distribution $(\varphi(Z))$ caused by a set of natural, climatic, and marketing variables. To separate parameters from variables, the latter and the former are respectively presented in capital and small letters:

$\operatorname{Max} U=Z-\varphi \cdot \sigma(Z)$

The risk-aversion coefficient of farmers shows the risk attitude of farmers while selecting between profiting and 166 risk aversion. Risk-neutral farmers $(\varphi=0)$ try to maximize their profits and cultivate profitable and high-risk crops. Risk-averse farmers $(\varphi>0)$ reject any risk, try cultivating crops with low risk, and sacrifice part of their profit to risk. Several theoretical studies (Friedman \& Savage, 1948; Von Neuman \& Morgenstern, 1944) and many experimental studies (Binswanger, 1980; Chavas, 2004) have shown that most farmers prefer risk aversion and try maximizing the utility instead of maximizing the profit. Ignoring farmers' risk-aversion behavior makes unrealistic and unacceptable results for management programs (Hazell \& Norton, 1986).

Equation 2 calculates the farm income, where $g m_{j r}$ is the gross profit per crop $(j)$ and technique $(r)$, which comes

173 from the difference between incomes (cost multiplied by yield) and production costs. $X_{j r}$ is the area under 174 cultivation, fco is the family's opportunity cost, flab $_{p}$ is the number of family's labor, $h l w$ is hired labor wage, $175 h l a b_{p}$ is the number of hired labor, $\mathrm{wpm}^{3}$ is the volumetric price of water, $W C$ is the amount of water used in the 176 farm, wpha is the irrigation water fee paid per hectare, and sirrg is the irrigated area in the farm (Esteve et al., 2015).

$$
z=\sum_{j} \sum_{r} g m_{j r} . X_{j r}-f c o \sum_{p} f l a b_{p}-h l w \cdot \sum_{p} h l a b_{p}-w p m^{3} W C-w p h a s i r r g
$$

177 The above maximizing function has some constraints, such as water limitation (the most affecting factor due to 178 climate change), which are presented in Equations 3-8:

$$
\begin{array}{ll}
\sum_{j=1}^{J} \frac{w_{j s r}}{e f f_{r}} x_{j s} \leq W_{\mathrm{s}} & \forall \mathrm{s} \\
\sum_{j=1}^{J} l_{j s} x_{j s} \leq L_{s} & \forall s \\
\sum_{j=1}^{J} m_{j s} x_{j s} \leq M_{s} & \forall s \\
\sum_{j=1}^{J} f_{t j s} x_{j s} \leq F_{t s} & \forall \mathrm{t}, s \\
\sum_{j=1}^{J} p e_{z j s} x_{j s} \leq P E_{z s} & \forall \mathrm{z}, \mathrm{s}
\end{array}
$$




$$
\sum_{j=1}^{J} \sum_{s=1}^{S} \operatorname{Sch}_{j s} x_{j s} \leq A
$$

Inequality (3) indicates water use restrictions. In this constraint, $W_{j s \mathrm{~s}}$ is the water required during the season $s$. eff $r$ is the irrigation efficiency in per region $(r)$, and $W_{s}$ is the total available water $\left(\mathrm{m}^{3}\right)$ during season $s$. In inequality 4 , $l_{j s}$ shows the number of hired labor for one-hectare cultivation of crop $j$ in season $s$, and $L s$ shows the total available labor during season $s$. Inequality 5 is related to the periods of using agricultural machinery, in which $m_{j s}$ shows the hours of using machineries in one hectare of crop $j$ in season $s$, and $M_{S}$ shows total available hours of agricultural machinery during season $s$.

Inequalities (6) and (7) are about fertilizers and pesticides, respectively. $F_{t s}$ shows total available fertilizer of type $(t)$ during season $s$, and $P E_{z s}$ is applied for total available pesticide of per type of it $(z)$ during $s$. Constraint 8 is about land in which $A$ shows total farmland area and $S c h_{j}$ denotes cropping area per crop (j) in season $s$. Farmers' risk aversion is used for model calibration. The accuracy of the calibrated model was estimated by the percentage of absolute deviation (PAD) calculated through Equation (9).

$$
P A D=\frac{\sum_{c-n}^{n}\left|\bar{X}_{c}-X_{c}\right|}{\sum_{c-n}^{n} \bar{X}_{c}} \times 100
$$

In this equation, $\bar{X}_{c}$ is the observed (\%) and stimulated (\%) amount. The proper calibration happens when PAD approaches zero. Model validation is done using statistical parameters for comparing the simulated and observed land and labor.

\subsection{The hydrologic model}

There are various models for estimating the water condition in the basin level in the hydrologic section. For choosing the right model, however, one should pay attention to available data and facilities, model structure, and its connection to other sections. Due to the availability of the software, various capabilities, and the possibility of using it along with economic modeling, WEAP is an appropriate model in hydro-economic modeling, which was also highlighted in related literature. The current research applied MABIA in WEAP for simulating daily evapotranspiration and estimating the yield and water requirement of crops (Allen, 1998). MABIA uses a two-part crop coefficient $(\mathrm{Kc})$ described in FAO-56, in which $\mathrm{K}_{\mathrm{c}}$ is divided into two crop coefficient base $(\mathrm{Kcb})$ and a secondary factor, called evaporation coefficient (Ke), which shows the evaporation from soil surface. When the surface of soil is dry, but there is considerable moisture in the root area that can compensate for the evaporation of the crop, the base crop coefficient shows a real ET situation (Sieber \& Purkey, 2011). MABIA generates daily data while WEAP generates data on a monthly basis. Thus, daily data generated by MABIA are calculated for monthly use of WEAP.

The hydrologic model (WEAP-MABIA) is calibrated based on parameters such as soil water capacity, deep water capacity, runoff resistance factor, rootzone conductivity, deep conductivity, and preferred flow direction. The validity of the model is tested after the calibration stage to examine the capability of the model for making correct predictions. Keeping the fixed variables and calibrated parameters constant, the outcomes of the model are compared to observed data from other periods. Calibration is done manually through statistical parameters for comparing observed and 
simulated models. The accuracy is also tested using Nash Sutcliffe coefficient (NASH) and error of bias (Blanco-

211 Gutiérrez et al., 2013)

$$
\begin{aligned}
& N A S H=1-\frac{\sum_{i=1}^{n}\left(Q_{s, i}-Q_{o, i}\right)^{2}}{\sum_{i=1}^{n}\left(Q_{\mathrm{o}, i}-\overline{Q_{o}}\right)^{2}} \\
& B I A S=100 \times \frac{\overline{Q_{s}}-\overline{Q_{o}}}{\bar{Q}_{o}}
\end{aligned}
$$

212 In this formula, $\bar{Q}_{s}$ and $\bar{Q}_{o}$ are simulation and estimated values, respectively. Also, $Q_{s, i}$ and $Q_{o, i}$ are simulation 213 and observed values according to $i$ as the time and $n$ as the number of observations. Calibration is considered 214 appropriate when BIAS approaches zero and Nash moves toward 1.

\subsection{Model integration}

The hydrological and economic models run independently; however, the output of one model is used as an input for the other one (Mainuddin et al., 2007; Maneta et al., 2009). The hydro-economic model starts with the economic model, and optimal cropping pattern $\left(X_{j r}\right)$ is obtained through maximizing expected utilities of farmers in Quadratic risk programming. The estimated cropping pattern is used as the input for WEAP model and MABIA estimates the water requirement, water allocation, and crop yield.

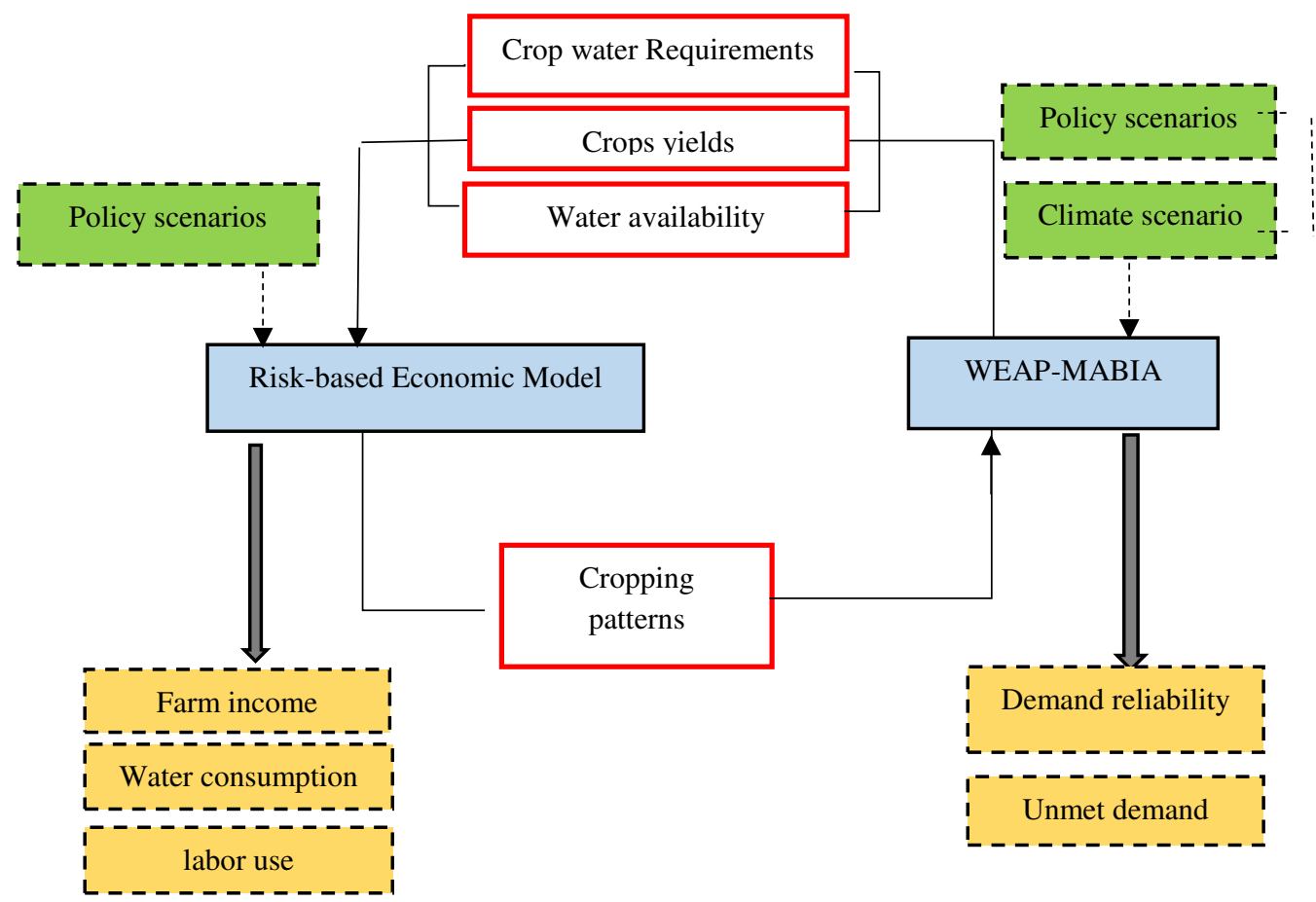

Fig. 2. An overview of the hydro-economic model 
MPM is run again after the first simulation of the hydro-economic model. The economic model determines the optimal cropping patterns based on the outcome of WEAP model for the new conditions. The adjusted cropping pattern is then used as an input for WEAP model to determine water allocation, demand supply, and water requirements under the new conditions. The process frequently continues to find a cropping pattern by which the hydrologic system is able to supply the water requirement of crops. Figure 2 represents the conceptual relationship between the hydrological and economic models.

Increasing irrigation efficiency through implementing a change in irrigation systems from surface to pressurized irrigation is one decided scenario for managing water resources. It is assumed that $j$ crop in $i$ location is irrigated by surface irrigation method. Considering the amount of evapotranspiration during irrigation seasons as $E T_{a c t j}$, and the whole irrigation efficiency as $E F_{\text {irrsurff }}$, the irrigation water consumption of the crop $\left(\mathrm{V}_{\text {irrsurf }}\right)$ is calculated as:

$$
V_{\text {irssurfj }}=\frac{E T_{\text {act } j}}{E F_{\text {irssurf }_{j}}}
$$

As the main goal of the current research is to reduce water consumption in agriculture, it is assumed that the amount of the actual evapotranspiration of crops in the suggested management scenarios is equal to actual evapotranspiration of crops in the current condition. The irrigation efficiency of the crop will increase from $E F_{\text {irrsurf } j}$ to $E F_{\text {irrprzj }}$ by changing the irrigation system from surface to pressurized system. Thus, the water consumption of $\mathrm{j}$ for the crop is calculated through:

$$
V_{i r p r r j}=\frac{E T_{a c t j}}{E F_{i r p r i j}}
$$

$V_{\text {irprpz }}$ is the amount of water consumption of $\mathrm{j}$ for the crop in pressurized irrigation scenario, and $E F_{\text {irrprzj }}$ is the efficiency of whole irrigation during pressurized irrigation. Thus, the amount and percentage of reduction in water consumption for producing crop $j$ in a scenario of improvement irrigation system from surface to pressure are equal to:

$$
\begin{aligned}
& \Delta V_{i r p r r j}=\frac{E T_{a c t j}}{E F_{i r s s u r j}}-\frac{E T_{a c t j}}{E F_{i r p p r j}}
\end{aligned}
$$

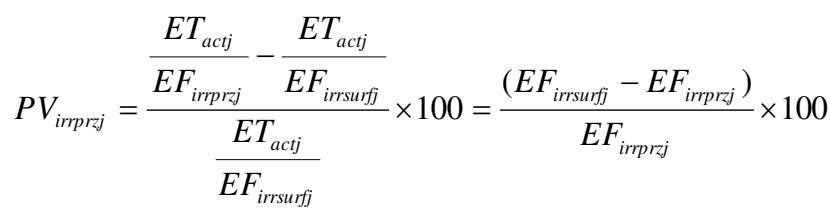

$242 \Delta \mathrm{V}_{\text {irrprzj }}$ is the amount of reduction in water consumption for $j$ as a crop due to the substitution of surface irrigation 243 with pressurized irrigation $\left(\mathrm{EF}_{\text {irrprzzj }}\right)$. The $P V_{\text {irpr } r j}$ variable shows the percentage of reduction.

244 The study of the effects of climate change in local scale is dependent on the estimation of the future climate. Such estimates are done through climate models, and more importantly, by General Circulation Models (GCM). The current

246 study applied HadCM3 as the general circulation model. LARS-WG was used for downscaling climatic generator and 247 for producing rainfall, radiation, and minimum and maximum temperatures in a station under current and future 
climatic conditions on a daily basis. Also, LARS-WG was applied for producing daily microscale data under A2, B1, and A1B emission scenarios. All required variables, such as information about input values, production quantities, and economic information (crop price, fertilizer, pesticides, labor, etc.) were collected from 210 questionnaires filled by farmers during 2018. The questionnaire included five products, including rainfed wheat, rainfed barley, potato, alfalfa, and bean, which were selected through stratified random sampling. The data and information about the current status and other information of the area were provided by the Agriculture Organization of Sarab. The quadratic risk programming (QRP) was solved in an optimizer software (GAMS). Furthermore, a part of data that covered climatic factors for previous 30 years was collected from the East Azerbaijan Meteorological Organization.

\section{Results}

Climate change scenarios were simulated using the LARS-WG model with three emission scenarios of A2, B1, and A1B for the period between 2018 and 2050. The results showed that the average rainfall decreased in the range of 21-38\% under the emission scenarios of A2, B1, and AIB during 2018-2050 period. In the next period of 20182050 , the average annual temperature will also increase by $2.5^{\circ} \mathrm{C}$ compared to the baseline period under $\mathrm{A} 2$ scenario. This value is slightly lower for $\mathrm{B} 1$ and $\mathrm{A} 1 \mathrm{~B}$ scenarios and under these scenarios, the average annual temperature will increase by 2.4 and $1.7^{\circ} \mathrm{C}$, respectively compared to the baseline. Among the three greenhouse gas emission scenarios, A2 was recognized as the most severe emission scenario.

The current study used WEAP model for simulating the hydrologic condition of the Ajichay basin. Table 1 illustrates the area under cultivation for each crop during the base year 2018. Wheat includes the largest cultivation area, whereas bean has the smallest cultivation area. Changes in the crop area due to climate change show that the biggest change in the cropping area belongs to A2. Alfalfa had the greatest reduction in the cropping area in Sarab plain, which was due to its high-water requirement. As result of climate change, therefore, the cropping area of alfalfa will decrease to $52.8 \%$ under the A2 scenario. Although potato has a high-water requirement, it has a less reduction in the cropping area due to its high profit. Barley and wheat revealed 48.5 and $131.5 \%$ increases in cropping areas due to their lower water requirements. In the second and third scenarios (B1 \& A1B), there is also a reduction in the area under cultivation for potatoes, alfalfa, and beans, and an increase for the cultivation of wheat and barley.

273 Table 1 Changes in cropping area under climate change scenarios (\%)

\begin{tabular}{|c|c|c|c|c|c|}
\hline & & $\begin{array}{c}\text { Cropping } \\
\text { area }\end{array}$ & The perce & $\begin{array}{l}\text { ariation } \\
\text { scenari }\end{array}$ & nate change \\
\hline Aquifer & Crop & Base year & $\mathrm{A} 2$ & B1 & A1B \\
\hline \multirow{5}{*}{ Sarab } & Wheat & 5209 & +48.5 & +39.4 & +37.4 \\
\hline & Barley & 1535 & +131.5 & +108.3 & +112.2 \\
\hline & Alfalfa & 6502 & -52.8 & -46.1 & -49.4 \\
\hline & Potato & 2356 & -38.3 & -31.1 & -33.7 \\
\hline & Bean & 548 & -38.1 & -33.2 & -31.4 \\
\hline Asbforushan1 & Wheat & 4588 & +13.8 & +5.1 & +5.1 \\
\hline
\end{tabular}




\begin{tabular}{|c|c|c|c|c|c|}
\hline & Barley & 1183 & +34.6 & +26.9 & +27.3 \\
\hline & Alfalfa & 2747 & -35.6 & -28.5 & -28.3 \\
\hline & Potato & 269 & -19.1 & -21.2 & -21.2 \\
\hline & Bean & 62 & -22.9 & -16.6 & -20.3 \\
\hline \multirow{5}{*}{ Asbforushan2 } & Wheat & 1254 & +9.9 & +5.3 & +7.1 \\
\hline & Barley & 406 & +43.6 & +21.6 & +36.3 \\
\hline & Alfalfa & 895 & -24.6 & -17.9 & -18.3 \\
\hline & Potato & 262 & -27.7 & -22.1 & -26.6 \\
\hline & Bean & 55 & -44.1 & -39.7 & -40 \\
\hline \multirow{5}{*}{ Duzduzan } & Wheat & 2629 & +1.1 & -4.2 & -2.2 \\
\hline & Barley & 636 & +61.4 & +49.4 & +54.6 \\
\hline & Alfalfa & 683 & +37.1 & +12.3 & +25.7 \\
\hline & Potato & 1612 & -20.6 & -23.6 & -23.4 \\
\hline & Bean & 480 & -71.1 & -68.3 & -63.6 \\
\hline \multirow{5}{*}{ Mehraban 1} & Wheat & 1721 & +7.4 & +5.2 & +5.8 \\
\hline & Barley & 444 & +47.5 & +45.4 & +48 \\
\hline & Alfalfa & 1002 & -9.3 & -12.7 & -8.7 \\
\hline & Potato & 567 & -25.3 & -18.9 & -22.3 \\
\hline & Bean & 118 & -86.9 & -79.5 & -77.3 \\
\hline
\end{tabular}

Table 2 shows changes in crop yield under climate change scenarios. The results of simulations revealed that the crop yields would undergo a decrease after climate change scenarios compared to the baseline. The most considerable

277 yield reduction belongs to the A2 scenario in which potato will have the highest yield reduction of 17\%. The crop 278 yields of barley and wheat shows a slight reduction suggesting the appropriate climatic condition, such as average 279 temperatures and the length of growing season. Thus, these two products have larger cropping areas in the climatic scenarios. Climate change will affect plant growth by temperature rise and low rainfall. Therefore, changes in the

281 climate and an increase in the temperature are serious future threats to the crop yield and farmers' incomes, resulting 282 in a lack of motivation to produce.

283 Table 2 Changes in crop yield and water requirment under climate change scenarios (\%)

\begin{tabular}{ccccccccc}
\hline & \multicolumn{2}{c}{ Baseline } & \multicolumn{2}{c}{ A2 Scenario } & \multicolumn{2}{c}{ B1 Scenario } & \multicolumn{2}{c}{ A1B Scenario } \\
\hline \multirow{2}{*}{ crops } & $\begin{array}{c}\text { Yield } \\
\text { (Tone) }\end{array}$ & $\begin{array}{c}\text { Water } \\
\text { requirement } \\
\left(\mathrm{M}^{3}\right)\end{array}$ & $\begin{array}{c}\text { Yield } \\
(\% \Delta)\end{array}$ & $\begin{array}{c}\text { Water } \\
\text { requirement }\end{array}$ & $\begin{array}{c}\text { Yield } \\
(\% \Delta)\end{array}$ & $\begin{array}{c}\text { Water } \\
\text { requirement }\end{array}$ & $\begin{array}{c}\text { Yield } \\
(\% \Delta)\end{array}$ & $\begin{array}{c}\text { Water } \\
\text { requirement }\end{array}$ \\
\hline Wheat & 5.16 & 3923 & -9.5 & +8.3 & -7.1 & +6.7 & -8.3 & +7.9 \\
\hline Barley & 3.23 & 3923 & -8.8 & +7.2 & -5.4 & +6.2 & -5.3 & +6.7 \\
\hline
\end{tabular}




\begin{tabular}{cccccccccc}
\hline Potato & 27.61 & 7584 & -17 & +11 & -9.6 & +9.5 & -13 & +10.5 \\
\hline Alfalfa & 10.68 & 6904 & -11 & +9.8 & -7.5 & +8.8 & -8.7 & +9.4 \\
\hline Bean & 2.5 & 5591 & -13 & +14 & -10.9 & +11.5 & -11.5 & +12.8 \\
\hline
\end{tabular}

284

According to the table 2, the water requirement of the crops under under climate change scenarios will increase during the 2018-2050 period. The A2 emission scenario will lead to maximum water demand. Compared to the baseline, for instance, the water requirement of beans will have an increase of $14 \%$ after the A 2 emission scenario, which will increase the water requirement from $5591 \mathrm{~m}^{3}$ to $6375 \mathrm{~m}^{3}$ per hectare. Compared to the other products, the water requirement of barley shows a small increase, suggesting its adaptability to the climate.

Table 3 represents the outcome of applying the climate change scenario and its effects on the amount of available water and the degree of reliability for supplying water for agricultural areas during 2018-2050. It is apparent from Table 3 that climate change results in a decrease in available water and water supply reliability for agricultural purposes. The available water for irrigation areas had $21.92 \%$ decrease after applying the climate change scenario. More specifically, there was 31.01\% decrease in the available water in Asbforushan 2 area, while Sarab witnessed $12.29 \%$ decrease. The reason for such a reduction in Asbforushan 2 area is the location, which is placed downstream of the Ajichay basin, and the intensified effects of climate change on water availability.

Table 3 The comparison of available water and the reliability in baseline and climate change scenarios

\begin{tabular}{cccccc}
\hline & & Baseline & & \multicolumn{2}{c}{ A2 Climate Change Scenario } \\
\hline Aquifer & Irrigation efficiency & Available water $\left(\mathrm{mm}^{3}\right)$ & Reliability & Available water & Reliability \\
& & & $(\%)$ & $(\%)$ & 74.31 \\
\hline Sarab & 41 & 132.57 & 93.68 & -12.29 & -18.21 \\
\hline Asbdorushan 1 & 41 & 66.6 & 89.34 & -31.01 & 55.71 \\
\hline Asbforushan 2 & 41 & 21.9 & 71.42 & -25.81 & 75.41 \\
\hline Duzduzan & 44 & 45.6 & 83.12 & -22.32 & 62.35 \\
\hline Mehraban 1 & 43 & 34.43 & 87.10 & -21.92 & 68.89 \\
\hline Average & 42 & 60.22 & 84.93 & & \\
\hline
\end{tabular}

Table 3 presents the system percentage of reliability in supplying the demand of each aquifer during the climate change scenario (A2). Based on the findings, it is assumed that there is $74.31 \%$ probability for supplying the demand of Sarab aquifer if the future years continue to have a decrease in rainfall and an increase in the temperature. Also, supplying the demands in Asbforushan1 is possible with a probability of $76.71 \%$. Furthermore, the probabilities of supplying the water demands of Asbsforushan2, Duzduzan, and Mehraban are 55.71\%, 75.41\%, and 62.35\%, respectively. This result indicates a weak probability of supplying water for agricultural purposes and highlights the high pressure that climate change can put on agriculture. Furthermore, the mean for water supply reliability in the subbasin decreased from $84.93 \%$ to $62.35 \%$. 
The second column of Table 3 presents the irrigation efficiency for each agricultural area. The average irrigation efficiency of the area is equal to $42 \%$, and Duzduzan and Mehraban have the highest averages of $44 \%$ and $4 \%$, respectively. Based on the data at the country level, the average efficiencies for pressurized and surface irrigation systems are 66.6 and 53.6\%, respectively. Moreover, comparing the various methods of pressurized irrigation reveals that the average irrigation efficiencies in sprinkler and drop irrigation methods are $62.1 \%$ and $77.1 \%$, respectively. Comparing the basin irrigation efficiency with the country average indicates a low efficiency level at the basin. Thus, applying modern irrigation methods with a higher efficiency, such as expanding pressurized irrigation, is suggested as a method to prevent climate change. Thus, $25 \%$ optimization in the efficiency of irrigation (which is the difference between the efficiency value of the basin and the country) as a scenario is introduced as an adaptive strategy for reducing the effects of climate change in all agricultural areas.

In the next step, the effects of water resource management scenarios were calculated on profits, cropping patterns, and the employment of agricultural labor. The scenarios include a $20 \%$ reduction in agricultural water consumption and an increase in the irrigation efficiency. Table 4 presents the percentage of variation in profits during the implementation of the scenario of reducing the share of water in agricultural sectors, as well as the application of the scenario following climate change. It is clear from Table 4 that the profit in each region will decrease compared to the baseline by applying the agricultural water reduction scenario of along with the climate change. The highest reduction in profit levels belongs to the simultaneous application of agricultural water reduction and A2 emission scenarios. Compared to the baseline, the profit in agricultural area of Duzduzan reveals 18\% decrease following the agricultural water reduction and $\mathrm{A} 2$ emission scenarios. The highest reduction rate belongs to Asbforushan 2 area with $28 \%$ decline compared to the baseline. There are many reasons for the decrease in profits, including reductions in crop yields as a result of climate change or decreases in cropping areas of profitable products (potato, bean or alfalfa). Table 4 shows the percentage changes in farmer's profit during the implementation of the agricultural water reduction scenario and applying this scenario following climate change.

Table 4 Changes in farmers profit under agricultural water reduction scenario compared to the baseline (\%)

Agricultural water reduction scenario
Agricultural water reduction scenario along with climate change scenario

\begin{tabular}{ccccc}
\hline Aquifer & & A1 & B2 & A1B \\
\hline Sarab & -12 & -22 & -16.4 & -19 \\
\hline Asbforushan 1 & -16 & -20 & -16.8 & -17.4 \\
\hline Asbforushan 2 & -18 & -28 & -20.1 & -22.3 \\
\hline Duzduzan & -13 & -18 & -17.2 & -17.3 \\
\hline Mehraban 1 & -8 & -15 & -11.1 & -13.3 \\
\hline
\end{tabular}

331

Table 5 presents the profits in each sub-basin following increasing irrigation efficiency scenario (EFF) in baseline and climate change scenarios (CC). The profit in all the sub-basins under investigation had a rise after increasing the irrigation efficiency. For instance, there is a $16 \%$ increase in profits in the Duzduzan area compared to the baseline. The lowest profit increase belonged to Sarab and Asbforushan 2 areas, which had 18\% and 12\% increases, 
respectively. The data in Table 5 reveals that implementing this scenario along with climate change can cause a profit increase. Thus, increasing irrigation efficiency will not only help the efficient use of water but will also maintain the welfare of farmers in each area by guarantying sufficient profits.

Table 5 Changes in farmer's profit under increasing irrigation efficiency scenario compared to the baseline (\%) Increasing irrigation efficiency scenario along with the climate change scenario

\begin{tabular}{ccccc}
\hline Aquifer & $\begin{array}{c}\text { Increasing irrigation } \\
\text { efficiency scenario }\end{array}$ & A2 & B1 & A1B \\
\hline Sarab & +18 & +9 & +12 & +11 \\
\hline Asbforushan 1 & +13 & +6.1 & +11 & +7.3 \\
\hline Asbforushan 2 & +12 & +1.4 & +3.3 & +3.2 \\
\hline Duzduzan & +16 & +3.8 & +8.9 & +7.6 \\
\hline Mehraban 1 & +15 & +10.3 & +11.2 & +9
\end{tabular}

Figure 3 presents the share of crops in the baseline, climate change, and climate change along with increasing the irrigation efficiency scenarios. The figure indicates that farmers reduced water demand, tried changing the cropping patterns to wheat and barley, and limited the cultivation of alfalfa, bean, and potato in the climate change scenario compared to the baseline. The simultaneous implementation of the climate change and increasing irrigation efficiency scenarios causes the expansion in the cultivation of potato, beans, and alfalfa compare to the baseline. Generally, the implementation of this scenario will cause an increase in farmers' profits and a decrease in water consumption.

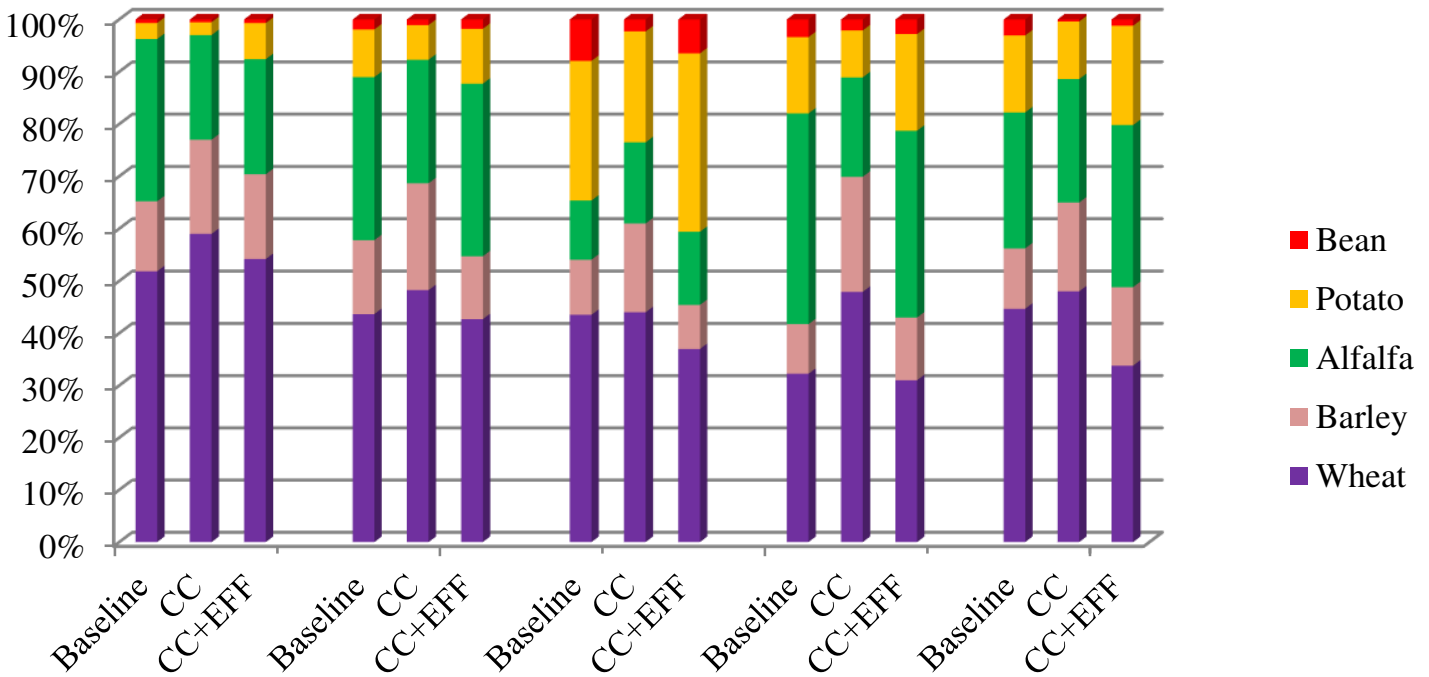

iC AS1

iC AS2

iC Duzduzan

iC Sarab

iC Mehraban

Fig. 3. Changes in cropping pattern under increasing irrigation efficiency scenario (\%) 
Compared to the baseline and climate change scenarios, the cropping pattern has changed in the agricultural water reduction (irr) scenario. As illustrated in Figure 4, the cropping pattern in the climate change scenario has moved toward crops with less water consumption. However, the simultaneous implementation of the climate change and agricultural water reduction scenarios has caused a decrease in the cultivation of crops with more water consumption. Although potato requires more water requirement than beans and alfalfa, it had a low reduction in area under cultivation due to high profits for farmers. In general, the cropping pattern is moving toward crops with less water requirement and more profits.

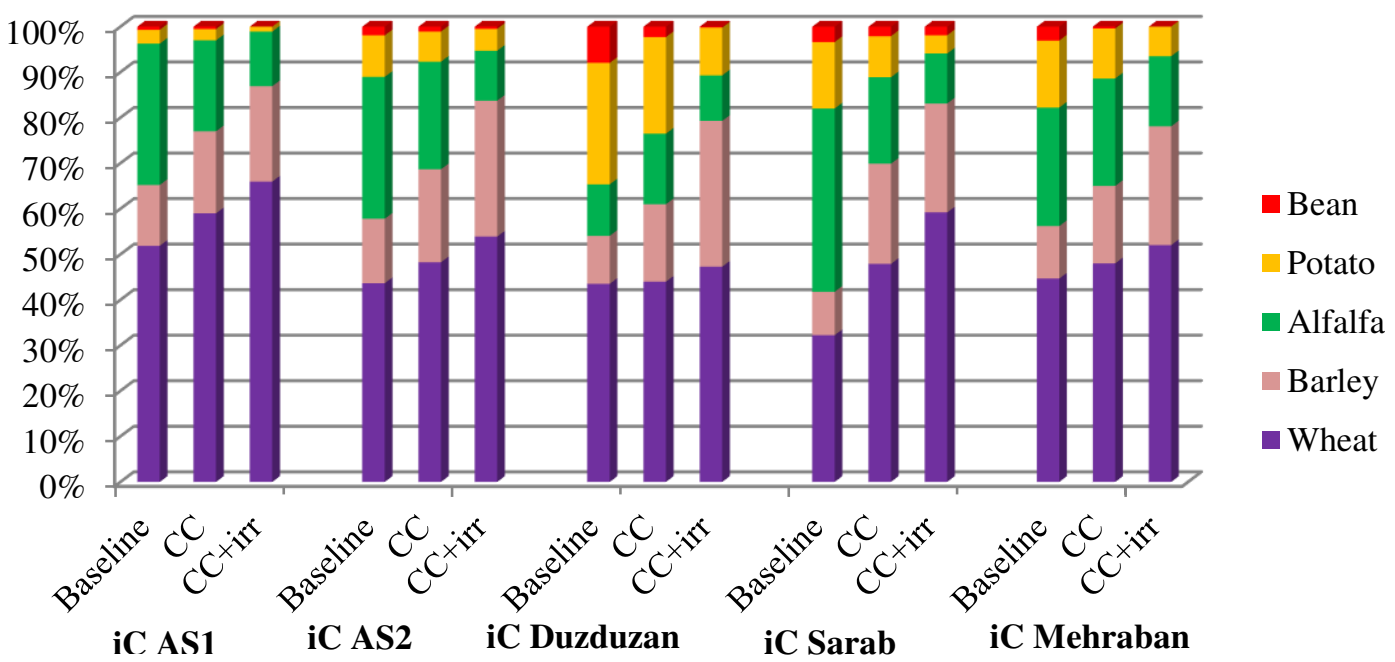

Fig. 4. Changes in cropping pattern under agricultural water reduction scenario (\%)

It is essential to study labor employment to predict the possible risk of losing jobs among farmers in case of severe climate change and reduction in agricultural water without considering substitute work opportunities. Table 6 shows changes in agricultural employment under management scenarios. Sarab has the greatest number of labors in the agricultural sector compared to other ones. Compared to the other parts of the basin, Sarab share of employment in agricultural work is 3.9 times more than the average in the other parts of the basin. Generally, it can be concluded that agriculture in Sarab city is more dependent on the Ajichay basin.

Table 6 Changes in agricultural employment under management scenarios compared to the baseline (\%)

\begin{tabular}{cccccc}
\hline Aquifer & A2 & $\begin{array}{c}\text { Agricultural } \\
\text { water } \\
\text { reduction } \\
\text { scenario }\end{array}$ & $\begin{array}{c}\text { Increasing } \\
\text { Irrigation } \\
\text { efficiency } \\
\text { scenario }\end{array}$ & $\begin{array}{c}\text { Agricultural water } \\
\text { reduction and A2 } \\
\text { scenarios }\end{array}$ & $\begin{array}{c}\text { Increasing Irrigation } \\
\text { efficiency and A2 } \\
\text { scenarios }\end{array}$ \\
\hline Sarab & -18 & -7 & -13 & -23 & -28 \\
\hline Asbforushan 1 & -11 & -4 & -7 & -12 & -16 \\
\hline Asbforushan 2 & -9.9 & -4.5 & -6 & -16 & -14.5 \\
\hline Duzduzan & -14.5 & -6 & -9 & -20
\end{tabular}




\begin{tabular}{cccccc}
\hline Mehraban 1 & -19 & -8 & -9.5 & -21 & -26 \\
\hline Average & -14.48 & -5.9 & -8.9 & -17.2 & -20.9 \\
\hline
\end{tabular}

Implementing the A2 scenario results in a $14.48 \%$ decrease in the average of agricultural employment in the area. The agricultural water reduction scenario alone results in a 5.9\% decrease in labor, whereas the increasing irrigation efficiency scenario has an $8.9 \%$ decrease. Applying the agricultural water reduction scenario along with climate change reduces the employment by $17.2 \%$ in the region by reducing the area under cultivation of crops that require a lot of labor. The increasing irrigation efficiency scenario also results in a $20.9 \%$ reduction in the labor employment. Maximum reduction rate in the labor employment belonged to Sarab after the application of agricultural water reduction and improving irrigation efficiency scenarios (23\% and 28\%, respectively) along with the emission of A2.

\section{Conclusions}

The current study aimed at filling the gap in the literature regarding the estimation of the effects of climate change on the agriculture subsector by suggesting a hydro-economic model. Based on the findings, climate change will bring about an increase in the temperature and a decrease in rainfalls, resulting in water decline in aquifers and discharge of the Aajichay River. The limited available water will cause a change in the cropping pattern and a reduction in the cultivation of water-consuming crops. Generally, there will be a shift toward crops with low water consumption and high profits. In line with the findings of the current study, a study by Maneta et al. (2009) revealed that farmers minimized the effects of decreased rainfalls by observing their profits. The findings of Morid and Bavani (2010) suggested that changing cropping patterns was the farmers' best response to the limited water condition.

Among the studied crops, beans had the highest reduction in the cultivation, which stemmed from its high-water requirement. However, potatoes also had a high-water requirement compared to beans but maintained a high cropping area due to higher gross profits. These findings are also confirmed by Lee et al. (2001), who concluded that during drought, farmers would shift to crops that require less water and worth more than a unit of water. Also, the economic effects are different depending on different crops. The findings of the current study revealed that wheat and barley had more resistance against the effects of climate change, and that shifting the patterns of cropping was an adaptive strategy for coping with the effects of climate change.

Climate change reduces labor employment. Additionally, the limited cultivation of crops (e.g. potatoes and beans) that require more labor leads to a decline in engaging agricultural workforce. Furthermore, there is no permission for changing the usage of agricultural lands; thus, farmers have to leave the lands and start illicit businesses, which bring about negative social consequences. A study by Salami et al. (2009) indicates a decline in the agricultural workforce of Iran, which is also confirmed in other studies (Qureshi et al., 2014; Esteve et al., 2015)

The optimization of irrigation efficiency is essential as it is related to the important issue of water investment. The average irrigation efficiency of the area is $42 \%$, which can be further optimized in the future. It is claimed that increasing the irrigation efficiency is an effective way, which can minimize the effects of climate change and help to adapt with the new conditions. 
The implementation of the agricultural water reduction scenario shows that although this scenario reduces water consumption, it decreases the profit and employment of the agricultural sector. The increasing irrigation efficiency scenario, along with an increase in profits, has a negative effect on the agricultural employment. The analysis of scenarios revealed that policies alone could not compensate for water related problems, and there is a need for plenty of scenarios for optimum results.

Overall, the findings of the current study revealed that without changing the management strategies, there would be a considerable reduction in crop yields in the near future. Optimizing management methods, selection of the right time for crop cultivation, optimized harvest, studying the feasibility of cultivating crops with shorter growth periods, and using cultivars with higher yields are the effective ways to confront the effects of climate change.

409

\section{Declarations}

\section{Ethics approval and consent to participate}

412 Not applicable.

\section{Consent for publication}

414 Not applicable.

\section{Availability of data and materials}

416 The datasets used and/or analyzed during the current study are available from the corresponding author on reasonable 417 request

418 Competing interests

419 The authors declare that they have no competing interests

420 Funding

421 Not applicable.

422 Authors' contributions Fatemeh Sani (FS)

423 Ghader Dashti (GD)

424 Abolfazl Majnooni (AM)

425 Javad Hosseinzad (JH)

426 FS and GD collected data. FS, GD and AM designed the model and the computational framework and analyzed the 427 data. FS, GD, AM and JH contributed to the interpretation of the results. FS and GD took the lead in writing the 428 manuscript. All authors provided critical feedback and helped shape the research, analysis and manuscript.

429 Authors' information

$430 \quad$ Affiliations

431

Department of Agricultural Economics, Faculty of Agriculture, University of Tabriz, Tabriz, Iran.

432 Fatemeh Sani

433 Department of Agricultural Economics, Faculty of Agriculture, University of Tabriz, Tabriz, Iran.

434 Ghader Dashti

435 Department of Water Engineering, Faculty of Agriculture, University of Tabriz, Tabriz, Iran.

436 Abolfazl Majnooni 
Tel.: +98 4143223677.Fax: +98 4143227475. E-mail address: fateme.sani69@yahoo.com

\section{References}

Aein R, Alizadeh H (2021) Integrated hydro-economic modeling for optimal design of development scheme of salinity affected irrigated agriculture in Helleh River Basin. Agric Water Manag 243, 106505. https://doi.org/10.1016/j.agwat.2020.106505

Ahmad D, Afzal M (2020) Climate change adaptation impact on cash crop productivity and income in Punjab province of Pakistan. Environ Sci Pollut Res 27, 30767-30777. https://doi.org/10.1007/s11356-020-09368-x

Allen RG, Pereira LS, Raes D, Smith M (1998) Crop evapotranspiration. Guidelines for computing crop water requirements. In: Irrigation and Drainage Paper. Italy, No. 56. FAO, Rome, 300 pp

Amin A, Iqbal J, Asghar A, Ribbe L (2018) Analysis of current and future water demands in the upper Indus Basin under IPCC Climate and socio-economic scenarios using a hydro-economic WEAP model. Water 10(5): 1-20. https://doi.org/10.3390/w10050537

Binswanger HP (1980) Attitudes toward risk: Experimental measurement in rural India. Am J Agric Econ 62 (3): 395 407. https://doi.org/10.2307/1240194

Blanco- Gutiérrez I, Varela-Ortega C, Purkey D (2013) Integrated assessment of policy interventions for promoting sustainable irrigation in semi-arid environments: a hydro-economic modeling approach. J Environ Manag 128:144-160. https://doi.org/10.1016/j.jenvman.2013.04.037

Buysse J, Van Huylenbroeck G, Lauwers L (2007) Normative, positive and econometric mathematical programming as tools for incorporation of multifunctionality in agricultural policy modeling. Agric Ecosyst Environ 120: 70-81. https://doi.org/10.1016/j.agee.2006.03.035

Cattivelli L, Rizza F, Badeck FW, Mazzucotelli E, Mastrangelo AM, Francia E, Mare C, Tondelli A, Michele Stanca A (2008) Drought tolerance improvement in crop plants: An integrated view from breeding to genomics. Field Crops Res 105: 1-14. https://doi.org/10.1016/j.fcr.2007.07.004

Chavas JP (2004) Risk analysis in theory and practice. Elsevier Academic Press. https://doi.org/10.1016/B978-0-12170621-0.X5000-7

Cheng B, Li H (2020) Impact of climate change and human activities on economic values produced by ecosystem service functions of rivers in water shortage area of Northwest China. Environ Sci Pollut Res 27, 26570-26578. https://doi.org/10.1007/s11356-020-08963-2

Eamen L, Brouwer R, Razavi S (2020) The economic impacts of water supply restrictions due to climate and policy change: A transboundary river basin supply-side input-output analysis. Ecol Econ 172, p.106532. https://doi.org/10.1016/j.ecolecon.2019.106532

Easterling WE, Chhetri N, Ni X (2003) Improving the realism of modeling agronomic adaptation to climate change: simulating technological substitution. Clim Change 60: 149-173. https://doi.org/10.1007/978-94-017-1984-1_7 
Esteve P, Varela-Ortega C, Blanco-Gutiérrez I, Downing TE (2015) A hydro-economic model for the assessment of climate change impacts and adaptation in irrigated agriculture. Ecol Econ 120, 49-58. https://doi.org/10.1016/j.ecolecon.2015.09.017

Expósito A, Beier F, Berbel J (2020) Hydro-Economic modelling for water-policy assessment Under Climate Change at a River Basin Scale: A Review. Water 12(6), 1559. http://dx.doi.org/10.3390/w12061559

FAO WFP, IFAD (2012) The state of food insecurity in the world: economic growth is necessary but not sufficient to accelerate reduction of hunger and malnutrition, food and agricultural organization of the united nations (FAO), the international fund for agricultural development (IFAD), and the world food programming (WFP), FAO, Rome, Italy.

Foster T, Brozović N, Butler AP (2014) Modeling irrigation behavior in groundwater systems. Water Resour Res 50: 6370-6389. https://doi.org/10.1002/2014WR015620

Friedman M, Savage LJ (1948) The utility analysis of choices involving risk. J Polit Econ 56: 279-304. https://www.jstor.org/stable/1826045

Groves DG, Yates D, Tebaldi C (2008). Developing and applying uncertain global climate change projections for regional water management planning. Water Resour Res 44: 1-16. https://doi.org/10.1029/2008WR006964

Gul F, Jan D, Ashfaq M (2019). Assessing the socio-economic impact of climate change on wheat production in Khyber Pakhtunkhwa, Pakistan. Environ Sci Pollut Res 26, 6576-6585. https://doi.org/10.1007/s11356-01804109-7

GWP (Global Water Partnership) (2000) Integrated water resources management. Global water partnership TAC background Paper 4. Stockholm, Sweeden.

Hazell PB, Norton RD (1986) Mathematical programming for economic analysis in agriculture. Macmillan, New York. https://doi.org/10.2307/2531573

Kahil MT, Dinar A, Albic J (2015) Modeling water scarcity and droughts for policy adaptation to climate change in arid and semiarid regions. J Hydrol 522: 95-102. https://doi.org/10.1016/j.jhydrol.2014.12.042

Kemfert C (2009) Climate protection requirements the economic impact of climate change. Handbook Utility Management 725-739.

Knowling MJ, White JT, McDonald GW, Kim J, Moore C, Hemmings B (2020) Disentangling environmental and economic contributions to hydro-economic model output uncertainty: An example in the context of land-use change impact assessment. Environ Model Softw 127, 104623. https://doi.org/10.1016/j.envsoft.2020.104653

Laux P, Jäckel G, Tingem RM, Kunstmann H (2010) Impact of climate change on agricultural date adaptations productivity under rainfed conditions in Cameroon - a method to improve attainable crop yields by planting. Agric For Meteorol 150(9):1258-1271. https://doi.org/10.1016/j.agrformet.2010.05.008

Lee H, Sumner D, Howtt R (2001) Potential economic impacts of irrigation-water reductions estimated for Sacramento Valley. Calif Agric 55(2): 33-40. https://doi.org/10.3733/ca.v055n02p33

Mainuddin M, Kirby M, Qureshi ME (2007) Integrated hydrologic-economic modelling for analyzing water acquisition strategies in the Murray River Basin. Agric Water Manag 93: 123-135. 
Maneta MP, Torres MO, Wallender WW, Vosti S, Howitt R, Rodrigues L, Bassoi LH, Panday S (2009) A spatially distributed hydro-economic model to assess the effects of drought on land use, farm profits, and agricultural employment. Water Resour Res 45: 1-19. https://doi.org/10.1029/2008WR007534

Medellan-Azuara J, Harou JJ, Howitt RE (2010) Estimating economic value of agricultural water under changing conditions and the effects of spatial aggregation. Sci Total Environ 408(3): 5639-5648. https://doi.org/10.1016/j.scitotenv.2009.08.013

Morid S, Bavani ARM (2010) Exploration of potential adaptation strategies to climate change in the Zayandeh Rud irrigation system, Iran. Irrig Drain 59(2): 226-238. https://doi.org/10.1002/ird.459

Purkey DR, Joyce B, Vicuna S, Hanemann MW, Dale LL, Yates D, Dracup JAJ (2008) Robust analysis of future climate change impacts on water for agriculture and other sectors: a case study in the Sacramento Valley. Clim Change 87: 109-122. https://doi.org/10.1007/s10584-007-9375-8

Qureshi ME, Ahmad MuD, Whitten SM, Kirby M (2014) A multi-period positive mathematical programming approach for assessing economic impact of drought in the Murray-Darling Basin, Australia. Econ Model 39: 293304. https://doi.org/10.1016/j.econmod.2014.02.042

Rafiei Darani H, Kohansal MR, Ghorbani M, Saboohi M (2017) An integrated hydro-economic modeling to evaluate marketing reform policies of agricultural products. Bulgarian J Agric Sci 2 (2): 189-197.

Rosenzweig MR, Binswanger HP (1992) Wealth, weather risk, and the composition and profitability of agricultural investments. Econ J 103(416): 56-78. https://doi.org/10.2307/2234337

Salami H, Shahnooshi N, Thomson KJ (2009) The economic impacts of drought on the economy of Iran: An integration of linear programming and macro econometric modeling approaches. Ecol Econ 68(4): 1032-1039. https://doi.org/10.1016/j.ecolecon.2008.12.003

Sieber J, Purkey D (2011) User guide for WEAP21 (Water Evaluation and Planning System). Stockholm Environment Institute. Available online from: www. weap21.org.

Tramblay Y, Llasat MC, Randin C, Coppola E (2020) Climate change impacts on water resources in the Mediterranean. Reg Environ Change 20, 83. https://doi.org/10.1007/s10113-020-01665-y

Tubiello FN, Rosenzweig C, Goldbrg A, Jagtap S, jones JW (2002) Effect of climate change on s crop production: simulation results using two different GCM scenarios. Part 1: wheat, potato, maize, and citrus. Clim Res 20(3): 259-270. https://doi.org/10.3354/cr020259

ULRP (2018) Urmia Lake Restoration Program. www. http://www.ulrp.ir.

Varela-Ortega C, Blanco-Gutie'rrez I, Esteve P, Bharwani S, Fronzek S, Downing TE (2016) How can irrigated agriculture adapt to climate change? Insights from the Guadiana Basin in Spain. Reg Environ Change 16(1): 5970. https://doi.org/10.1007/s10113-014-0720-y

Varela-Ortega C, Blanco-Gutiérrez I, Swartz C, Downing TE (2011) Balancing groundwater conservation and rural livelihoods under water and climate uncertainties: an integrated hydro-economic modeling framework. Glob Environ Change 21(2): 604-619. https://doi.org/10.1016/j.gloenvcha.2010.12.001 
545 Veijalainen N, Dubrovin T, Marttunen M, Vehvileinen B (2010) Climate change impacts on water resources and lake 546 regulation in the Vuoksi watershed in Finland. Water Resour Manag 24: 3437-3459. 547 https://doi.org/10.1007/s11269-010-9614-z

548 Von Neuman J, Morgenstern O (1944) Theory of games and economic behavior. Princeton University Press, $549 \quad$ Princeton, NJ.

550 Wan L, Wang E, Yang X, Zhang F, Yin H (2012) Increasing yield potential of wheat-maize cropping system in the 551 North China Plain by climate change adaptation. Clim Change 113(3-4): 825-840. https://doi.org/10.1007/s10584552 011-0385-1

553 Zhang P, Zhang J, Chen M (2017) Economic impacts of climate change on agriculture: The importance of additional 554 climatic variables other than temperature and precipitation. $\mathrm{J}$ Environ Econ Manage 83: 8-31. $555 \quad$ https://doi.org/10.1016/j.jeem.2016.12.001 


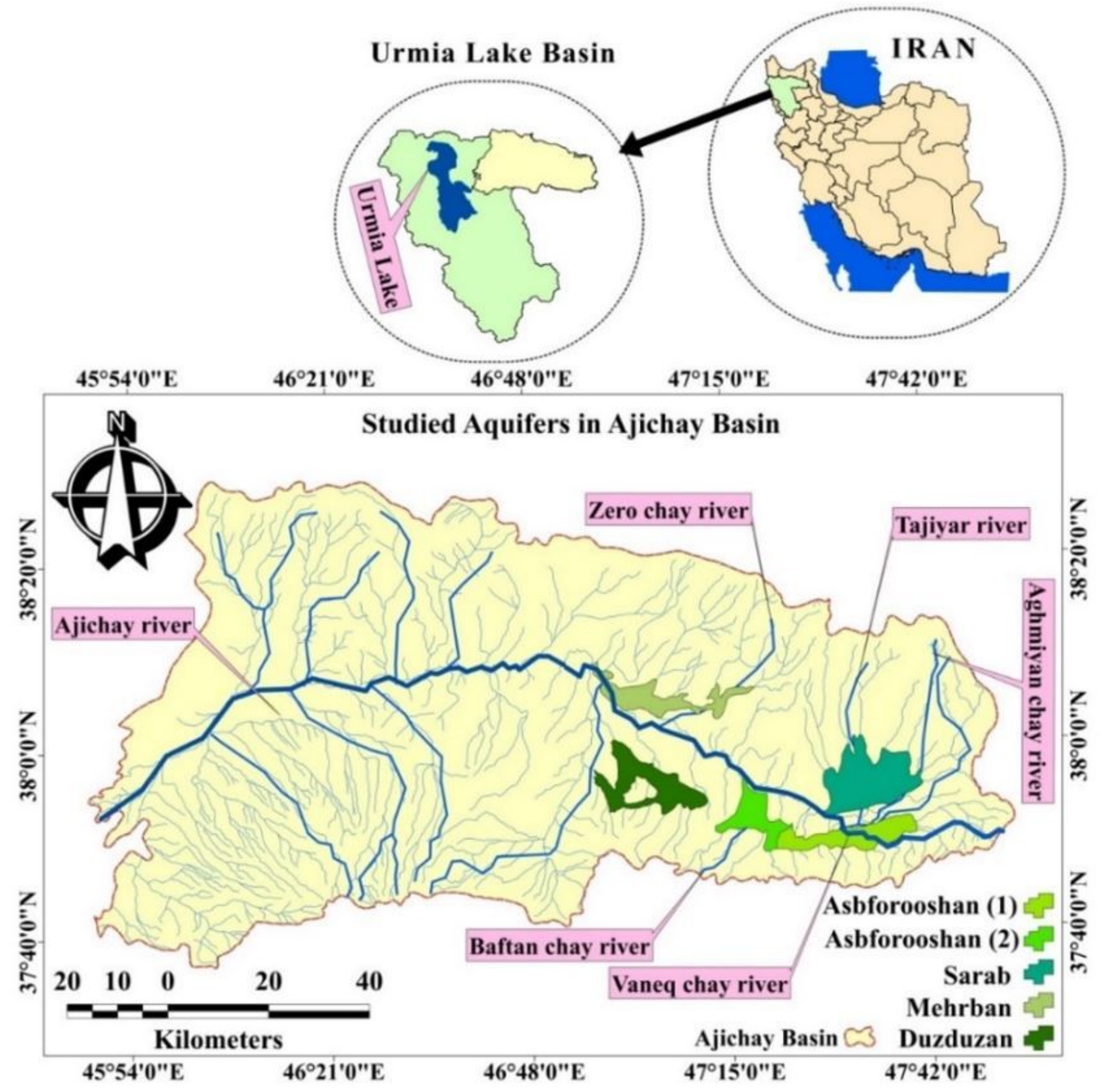

Figure 1

An Overview of the Ajichay Sub-basin. Note: The designations employed and the presentation of the material on this map do not imply the expression of any opinion whatsoever on the part of Research Square concerning the legal status of any country, territory, city or area or of its authorities, or concerning the delimitation of its frontiers or boundaries. This map has been provided by the authors. 


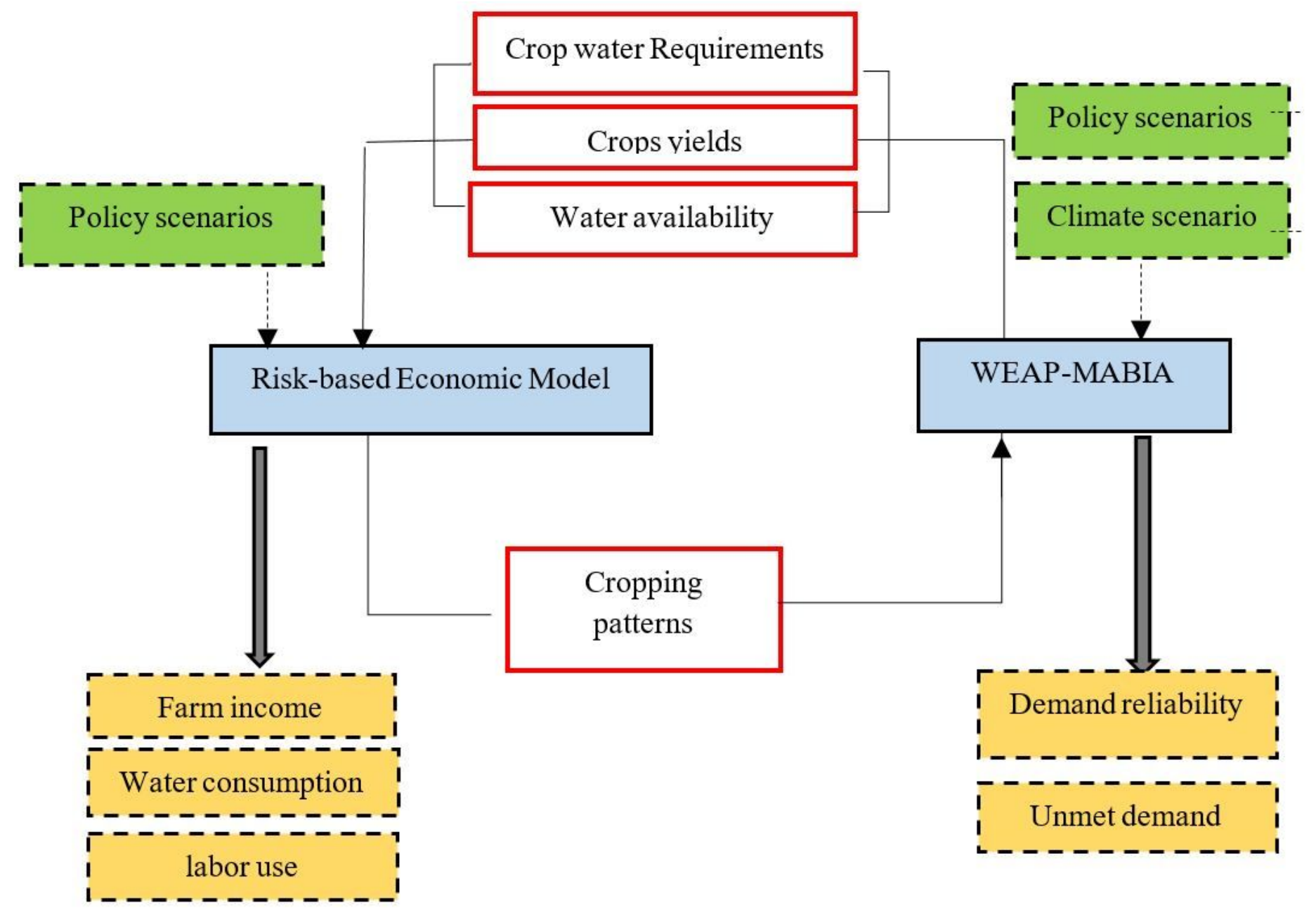

Figure 2

An overview of the hydro-economic model 


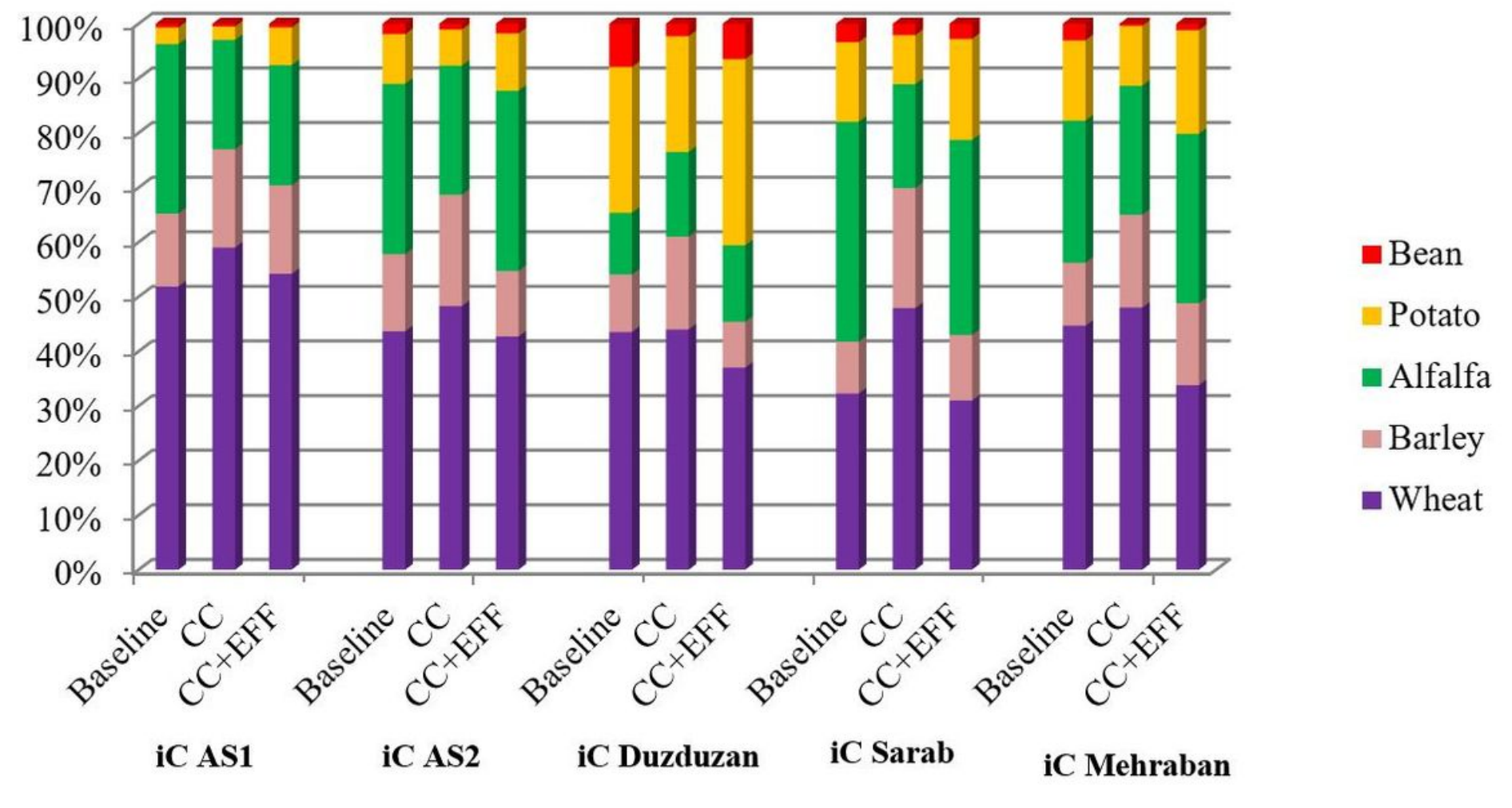

Figure 3

Changes in cropping pattern under increasing irrigation efficiency scenario (\%)

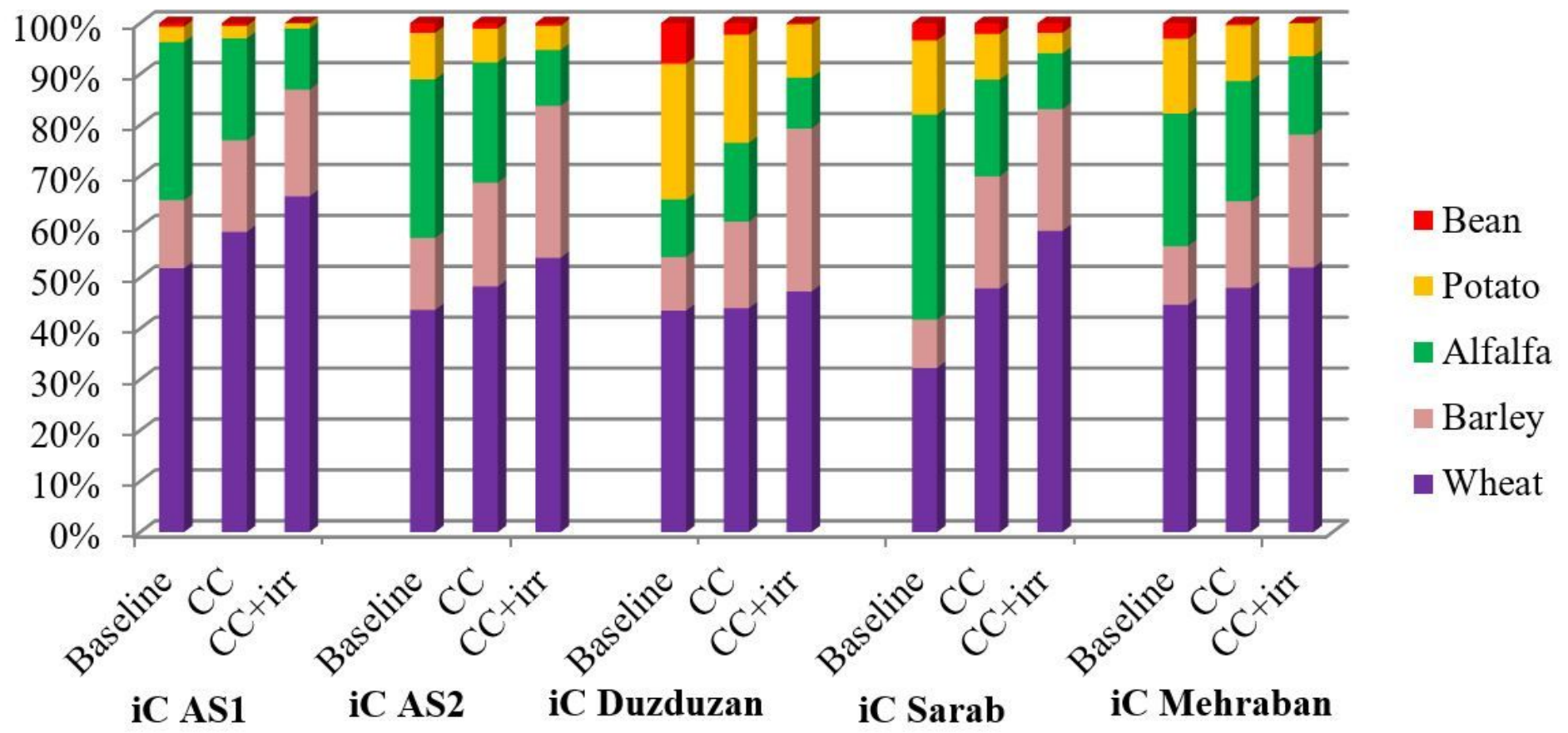

Figure 4

Changes in cropping pattern under agricultural water reduction scenario (\%) 